\section{Ray Society: Annual General Meeting}

ThE one hundred and seventh annual general meeting of the Ray Society was held on March 27. Two books, "British Spiders, Vol. 1", by G. H. Locket and A. F. Millidge, and "British Mysidacea", by the late Prof. W. M. Tattersall and Mrs. O. S. Tattersall, were published and distributed during the past year. It was announced that "British Spiders, Vol. 2", by G. H. Locket and A. F. Millidge, was being sent to press, that "Watsonian Vice-counties", by J. E. Dandy and F. W. B. H. Milne-Redhead, would soon be ready for press, and that "British Sponges, Vol. 1", by Dr. Maurice Burton, would be ready for press later in the year. Officers of the Society were elected as follows: President, Lieut.Col. R. B. Seymour Sewell; Vice-Presidents, Dr. John Hutchinson and Dr. Errol White; Honorary Treasurer, Lieut.-Col. W. P. C. Tenison; Foreign Secretary, Arthur Exell; Honorary Secretary, Dr. Maurice Burton; New Members of Council, Dr. B. F. Barnes, Dr. Edward Hindle, Mr. G. H. Locket amd Dr. H. W. Parker. An additional rule, passed at this meeting, permits the election, as honorary vicepresidents, of those who have rendered conspicuous services to the Society. The first to be elected are: Dr. G. P. Bidder, Dr. W. T. Calman, Prof. F. E. Weiss and Mr. J. Spedan Lewis.

\section{University of London}

Tre following appointments have been made in the University of London : Mr. W. R. Dean, lecturer in mathematics in the University of Cambridge, to the Goldsmid chair of mathematics tenable at University College, from October 1; Dr. H. C. Longuet-Higgins, reader in theoretical chemistry in the University of Manchester, to the University chair of theoretical physics tenable at King's College, from October 1. The title of reader has been conferred on the following in respect of the posts held by them in the Royal Veterinary College : Mr. H. R. Allen and Mr. J. W. H. Holmes (veterinary medicine); Mr. G. H. Arthur and Mr. G. C. Knight (veterinary surgery).

\section{University of Birmingham}

THE title of emeritus professor has been conferred by the University of Birmingham on Dame Hilda Lloyd, formerly professor of obstetrics and gynæcology, Prof. W. Stiles, formerly Mason professor of botany, and Prof. G. N. Watson, formerly Mason professor of mathematics.

The following appointments in the University have recently been announced : Dr. P. T. Matthews, to be lecturer in mathematical physics; N. A. Dudley, to be lecturer in engineering production; and W. D. Seymour, to be 'T.I. research fellow in engineering production.

\section{United States Army Medical Library}

REFERENCE was made in Nature of March 1, p. 355, to the services offered by this institution. We are informed that communications concerning photoprint or microfilm orders should be addressed directly to the Army Medical Library, 7th Street and Independence Avenue, S.W., Washington 25, D.C., and not to the Superintendent of Documents, U.S. Government Printing Office, Washington 25, D.C., who deals with the Current List of Medical Literature (subscriptions now $9 \cdot 75$ dollars a year and $12 \cdot 25$ dollars a year foreign).

\section{Announcements}

THE Institute for the Unity of Science is offering a prize of 500 dollars, with two additional prizes of 200 dollars each, for the best essays on "Mathematical Logic as a Tool of Analysis: Its Uses and Achievements in the Sciences and Philosophy". The competition is open to all and the essays may be written in English, French or German. They must not exceed 25,000 words and must be submitted before January 1, 1953. Further information can be obtained from the Institute for the Unity of Science, American Academy of Arts and Sciences, 28 Newbury Street, Boston 16, Mass.

THE Institute of Archæology of the University of London is organizing seven lectures, open to the public without ticket, on "Archæology and the Natural Sciences", to be held at the Institute, Inner Circle, Regent's Park, London, N.W.1, on successive Wednesdays at 8.15 p.m. commencing April 30. The lecturers will discuss respectively the relationship of archæology with geology, geomorphology, meteorology, plant ecology, metallurgy, agricultural botany and zoology.

ThE British Welding Research Association will hold a summer school on "Welding Design and Engineering" at Ashorne Hill, near Leamington Spa, Warwickshire, during July 16-25. The school will be divided into two courses: July 16-20, practical aspects of welding; and July 20-25, design, inspection and manufacturing problems. Further details can be obtained from the Association at 29 Park Crescent, London, W.1.

A BRITISH ornithological conference, arranged by the British Ornithologists' Union and the British Trust for Ornithology, in collaboration with the Monk's House Bird Observatory, will be held at the Pavilion, Bamburgh, Northumberland, during June 26-July 1. A number of excursions will be made to places of interest, including Farne Islands, and six papers will be read. Further details can be obtained from the secretary of the British Trust for Ornithology, 2 King Edward Street, Oxford.

UNDER the auspices of the Midlands Socjety for Analytical Chemistry, a short symposium on analytical chemistry, dealing with fundamental theory and original methods, will be held in the University of Birmingham during September 10-12, that is, immediately following the International Congress on Analytical Chemistry at Oxford. Further details can be obtained from the honorary secretary of the Society, W. T. Edwards, 100 Rymond Road, Birmingham 8.

THE North-Western Branch of the Institution of Electronics will be holding its seventh annual exhibition of electronic devices at the College of Technology, Sackville Street, Manchester 1, during July 15 (12-9 p.m.), July 16-17 (10 a.m.-9 p.m.) and July 18 (10 a.m. -5 p.m.). In addition to the usual commercial section of the exhibition, there will also be a scientific and industrial research section, incorporating exhibits from research associations and the universities. Admission will be by ticket, obtainable from the secretary, W. Birtwistle, 17 Blackwater Street, Rochdale, Lancs.

Erratum. In the article on "Lipid Metabolism" in Nature of April 5, p. 569, column 2, line 10 from bottom, for "stigmasterol as an anti-syphilitic factor" read "stigmasterol as the guinea pig anti-stiffness factor". 